\title{
Ecological restoration as objective, target, and tool in international biodiversity policy
}

\author{
Dolly Jørgensen $^{1}$
}

\begin{abstract}
Ecological restoration has been mainstreamed in international biodiversity policies in the last five years. I analyze statements about restoration in three international policies: the Convention for Biodiversity Strategic Plan 2011-2020 and Aichi Biodiversity Targets, the Convention for Biodiversity Decision XI/16 on ecosystem restoration, and the European Union's Biodiversity Strategy to 2020. I argue that restoration functions at three different levels in these policies: as an objective, as a target, and as a tool. Because restoration appears at all three levels, the policies encourage counting all restoration activity as meeting the objectives of the policy regardless of the activity's actual effect on ecosystem services or biodiversity more broadly. Reaching a numerical target for a restored area may not necessarily support the overarching policy goals of maintaining Earth's biodiversity and supporting ecosystem services.
\end{abstract}

Key Words: Convention on Biological Diversity; ecological restoration; European Union; policy

\section{INTRODUCTION}

Ecological restoration, defined by the Society for Ecological Restoration as the practice of "assisting the recovery of an ecosystem that has been degraded, damaged, or destroyed" (Society for Ecological Restoration International Science \& Policy Working Group 2004:3), has become a central component of modern conservation paradigms (Hobbs and Harris 2001, Suding 2011), even though divergent approaches have impeded rapid integration of restoration and conservation (Young 2000). Ecological restoration has also become integrated in global and regional biodiversity policies in the last five years (Aronson and Alexander 2013), as well as in sustainable economic policies (Neßhöver et al. 2011). Restoration has been named in the Convention for Biodiversity (CBD) targets for 2020 (CBD 2010a), as well as the European Union's (EU's) Biodiversity Strategy to 2020 (European Commission 2011a; see Box 1). In 2012, the CBD adopted a decision on ecological restoration that declared that "ecosystem restoration will play a critical role in achieving the Strategic Plan for Biodiversity 2011-2020, including the conservation of habitats and species" (CBD 2012:preamble).

Restoration has been embedded in biodiversity policy as part of a complex political system of goal setting and implementation toward the goal (e.g., Quental et al. 2011). Global environmental governance has relied on time-bound, quantitative objectives since the 1989 Montreal Protocol limited consumption and production of substances damaging to the ozone layer (Bille et al. 2010). The use of targets and indicators has become the norm in the public sector to assess performance (Castro 2011; see National Audit Office 2001 as an example), and this has spilled over into environmental governance.

Current biodiversity policies are built on four components: objectives, targets, tools, and indicators. The objective is what the policy is trying to achieve usually in a descriptive, qualitative way; targets give a clear sense of the direction for policy measures through specific and typically quantitative statements; and tools are the means or methods chosen to meet the targets and objectives (Tuominen and Himanen 2007). Indicators are the measurements used together to evaluate success or failure of a given tool to achieve an outcome (Jones et al. 2011).
I analyzed three international policies: the CBD Decision X/7 Strategic Plan 2011-2020 and Aichi Biodiversity Targets, the CBD Decision XI/16 on Ecosystem Restoration, and the EU Biodiversity Strategy to 2020 (see Box 1). My objective was to determine how restoration functions as an objective, target, and tool in these policy statements. How is restoration written into these policies at each of these three levels? What challenges does that create for reaching biodiversity conservation goals?

\section{Box 1:}

International biodiversity policy statements about restoration

Convention on Biodiversity Decision X/2. The Strategic Plan for Biodiversity 2011-2020 and the Aichi Biodiversity Targets

Mission of the Strategic Plan:

To take effective and urgent action to halt the loss of biodiversity in order to ensure that by 2020 ecosystems are resilient and continue to provide essential services, thereby securing the planet's variety of life, and contributing to human well-being, and poverty eradication. To ensure this, pressures on biodiversity are reduced, ecosystems are restored, biological resources are sustainably used and benefits arising out of utilization of genetic resources are shared in a fair and equitable manner; adequate financial resources are provided, capacities are enhanced, biodiversity issues and values mainstreamed, appropriate policies are effectively implemented, and decision-making is based on sound science and the precautionary approach.

\section{Strategic Goal D:}

Enhance the benefits to all from biodiversity and ecosystem services.

Aichi Target 14:

By 2020, ecosystems that provide essential services, including services related to water, and contribute to health, livelihoods, and well-being, are restored and safeguarded, taking into account the needs of women, indigenous and local communities, and the poor and vulnerable. 


\section{Aichi Target 15:}

By 2020, ecosystem resilience and the contribution of biodiversity to carbon stocks have been enhanced through conservation and restoration, including restoration of at least $15 \%$ of the degraded ecosystems, thereby contributing to climate change mitigation and adaptation and to combating desertification.

Convention on Biodiversity Decision XI/16. Ecosystem Restoration

...ecosystem restoration will play a critical role in achieving the Strategic Plan for Biodiversity 2011-2020, including the conservation of habitats and species, ...

1. Urges Parties and encourages other Governments and relevant organizations to make concerted efforts to achieve Aichi Biodiversity Targets 14 and 15 and targets 4 and 8 of the Global Strategy for Plant Conservation, and to contribute to the achievement of all the other Aichi Biodiversity Targets through ecosystem restoration through a range of activities depending on national circumstances....

1.(i) Takes into consideration strategic goal D of the Strategic Plan for Biodiversity 2011-2020 ("Enhance the benefits to all from biodiversity and ecosystem services") when making decisions regarding the allocation of resources to ecosystem restoration, giving due attention to the rehabilitation of degraded ecosystems in order to restore critical ecosystem functions and the delivery of benefits to people....

European Union Biodiversity Strategy to 2020

Headline target:

Halting the loss of biodiversity and the degradation of ecosystem services in the EU by 2020 , and restoring them in so far as feasible, while stepping up the EU contribution to averting global biodiversity loss.

Target 2:

By 2020, ecosystems and their services are maintained and enhanced by establishing green infrastructure and restoring at least $15 \%$ of degraded ecosystems.

\section{RESTORATION AS OBJECTIVE}

Within the CBD's current framework, the overall policy objective is "to halt the loss of biodiversity" (see Box 1). Although it may seem self-evident that international biodiversity policy aims to preserve biodiversity, what that means and why it should be done has been less clear in policy statements.

Biodiversity has often been justified through ecosystem services. A CBD fact sheet states that "the principal framework for expressing the 'usefulness' of biodiversity is through the concept of ecosystem services" (original italics; CBD 2010b:1). The CBD Strategic Plan for Biodiversity 2011-2020 refers to biodiversity as providing essential services for "securing the planet's variety of life and contributing to human well-being and poverty eradication" (see Box 1). Speaking of biodiversity and ecosystem services at the same time has become common, for example, with the foundation of the Intergovernmental Platform on Biodiversity and Ecosystem Services in 2012. The CBD Aichi Biodiversity Targets Strategic Goal D links biodiversity and ecosystem services when it sets a goal to "enhance the benefits to all from biodiversity and ecosystem services" (see Box 1).

The emphasis on ecosystem services in the CBD strategic plan has been characterized as a remedy for the failure of the 2010 Biodiversity Target to integrate sustainable development (Vélazquez Gomar 2014). Growing integration of ecosystem services has likewise been evident in EU policy post-2010 (Maes et al. 2013, Matzdorf and Meyer 2014). Ecosystem services language is seen as particularly useful for communication of motive and rationale for policy in the EU (Matzdorf and Meyer 2014). It is important to note, however, that although biodiversity is often assumed to be a provider of ecosystem services, it is not proven that increased ecosystem services leads to increased biodiversity, or vice versa (Egoh et al. 2014). Rather, biodiversity and ecosystem services have a multilayered relationship (Mace et al. 2012). Particularly in the case of actions targeting single services in isolation, conflicts between biodiversity objectives and services objectives may arise (Bullock et al. 2011).

In contrast to the CBD's statements that make biodiversity preservation the objective, the objective of the EU Biodiversity Strategy is much broader with three distinct parts: halt biodiversity loss, halt ecosystem service loss, and restore biodiversity and ecosystem services "in so far as feasible" (see Box 1). This means that ecosystem services have been elevated as a primary goal of the EU policy, and that restoration of both biodiversity and ecosystem services is a goal as well (European Commission 2011b:3). Restoration itself is thus presented an objective of the EU policy, although the inclusion of the phrase "in so far as feasible" limits the objective and leaves it open for interpretation at the local and regional levels (European Committee of the Regions 2010).

\section{RESTORATION AS TARGET}

Target setting in global environmental governance has become the norm since the United Nations Summit in Rio de Janeiro in 1992 adopted Agenda 21 (Jänicke and Jörgens 2006). Biodiversity targets are ideally written with long-term biodiversity objectives in mind (Mace et al. 2010). Billé at al. (2010) identified four expected potential outcomes of biodiversity targets: mobilizing people, legitimizing activities, increasing funding, and improving knowledge. In spite of these potential benefits, accomplishing change through international treaty targets is notoriously difficult when there are a large number of signatories or when targets are set from the outset rather than iteratively negotiated (Mace et al. 2013).

The Aichi targets directly link ecosystem services and ecological restoration, as does Decision XI/16 (Box 1). Both targets 14 and 15 are placed under Strategic Goal D, which is the goal containing reference to ecosystem services. Aichi Target 14 asks for restoration of ecosystem services "related to water and contributing to health, livelihoods and well-being"; Target 15 states that restoration activities should lead to increased ecosystem resilience and carbon stocks. The emphasis on the ecosystem services in restoration activities is reiterated in Decision $\mathrm{XI} / 16$, which urges the parties to prioritize restoration activities that "restore critical ecosystem functions and the delivery of benefits to people" (see Box 1). 
As biodiversity objectives and targets move from the global CBD scale to the EU regional scale, we would expect more specificity, i.e., targets that become more focused, efficient, and achievable as they move to regional scales (Mace et al. 2013). In the case of EU biodiversity policy, however, the regional targets have been more generically framed than the global targets. In early communications about the EU target for biodiversity after 2010, restoration was framed as a mode to "strengthen [ecosystem] resilience and sustain key services they provide, while also achieving conservation objectives and enabling Member States to adapt to climate change" (European Commission 2010:5). The final version of EU Target 2, on the other hand, is not specific about the ecosystem services of interest, claiming only that restoration should maintain and enhance ecosystems and their services.

Both CBD Target 15 and EU Target 2 include the quantitative target of restoring at least $15 \%$ of degraded ecosystems. Quantitative targets have become the standard of technocratic management because they can be measured and evaluated. The $15 \%$ target does not include a definition of what restoration entails (Jørgensen 2013). If it had done so, we could say that the target is an ecosystem in a particular state. Because it does not, the target is an ecosystem in a restored state, which is left up to interpretation.

\section{RESTORATION AS TOOL}

In addition to being an objective and a target, ecological restoration is a primary tool by which Aichi Target 15 and EU Target 2 are supposed to be achieved. According to Decision $\mathrm{XI} / 16$, ecosystem restoration is even a tool that should be used to "contribute to the achievement of all the other Aichi Biodiversity Targets" (see Box 1).

Concerns have been raised about the lack of definitions of restoration and degraded ecosystem when the targets were established, and how restoration should be counted toward targets (Jørgensen 2013). Decision XI/16 likewise requested that CBD "develop clear terms and definitions of ecosystem rehabilitation and restoration and clarify the desired outcomes of implementation of restoration activities" (CBD 2012:Section 5 (i)). Egoh et al. (2014) have argued that there is also a need for new information about biodiversity, ecosystem services, and restoration, as well as the relationships between them, if restoration as a tool is to be successful.

To address these types of concerns, the EU decided to "develop a strategic framework to set priorities for ecosystem restoration" as one of the actions in support of Target 2 (European Commission 2011a:Action 6a). EU activities so far have focused on how to measure and account for restoration toward the $15 \%$ goal. The report Priorities for the Restoration of Ecosystems and Their Services in the EU (Lammerant et al. 2013), commissioned to fulfill Action 6a, proposed that ecosystem condition be placed on a four-level scale based on numerous descriptors. In the proposed model, restoration is considered achieved when an ecosystem patch moves up on the scale, i.e., from level 4 to level 3 , level 3 to level 2, or level 2 to level 1 . The report suggests that the $15 \%$ restoration goal should be calculated on the basis of the total land and water area not already at level 1 in each member state. In the proposed model, restoration as an activity is a tool to reach the target of restoration of $15 \%$ of the eligible land or water.

\section{CHALLENGES WITH MULTIPLE ROLES FOR RESTORATION IN BIODIVERSITY POLICY}

Ecological restoration takes on three simultaneous but different roles in CBD and EU biodiversity policy: an objective, a target, and a tool. This creates challenges to actually bettering the biodiversity status of our planet. Because restoration itself has been listed as an objective of the EU policy, meeting the objective through a tool deployed to reach a numerical target becomes an accounting exercise. Parties have an incentive to maximize how much area they count as restored to meet the goal. Lammerant et al. (2013) advocates restoration as a process rather than end point, allowing member states to "engage in restoration activities and count them as part of the $15 \%$ without having to aim for full restoration within the 7 next years" (Lammerant et al. 2013:2.3.1). Climate change-induced habitat changes and areas affected by natural disasters are specifically excluded as degraded areas (Lammerant et al. 2013:2.3.3), even though logic would dictate that the biodiversity of those areas is being lost. The prioritization scheme does not require ecological restoration in Target 2 to be an activity that should improve ecosystem services to improve or maintain biodiversity, even though the CBD targets frame restoration within concerns about ecosystem services. In other words, the policies are written to encourage counting all restoration activity as meeting the objectives of the policy regardless of the activity's effect on ecosystem services or biodiversity more broadly.

Ultimately, although biodiversity targets may stimulate action, an "overemphasis on formal compliance with targets may in fact detract attention from the original objectives" (Mace et al. 2013:298). International targets can be misappropriated to support specific agendas or strategies of interest groups whether or not the outcome of those activities aligns with the policy objectives (Vandemoortele 2009). In this case, measuring restored area as generously as possible may obscure the primary goal of taking "effective and urgent action to halt the loss of biodiversity" (CBD 2010a:III.12).

If and when the CBD and EU biodiversity targets are implemented at regional and national scales, ecological restoration is going to play a large part. It is imperative, therefore, that thought be given to why restoration activities are being done and what their actual outcome with respect to biodiversity and ecosystem service preservation and recovery is expected to be. Because of the weight toward ecosystem services in the targets that mandate restoration activities, ecological restoration success should at a minimum be judged against service-based indicators.

Responses to this article can be read online at: http://www.ecologyandsociety.org/issues/responses. php/8149

\section{Acknowledgments:}

This research was supported by the Swedish Research Council Formas. 


\section{LITERATURE CITED}

Aronson J., and S. Alexander. 2013. Ecosystem restoration is now a global priority: time to roll up our sleeves. Restoration Ecology 21:293-296. http://dx.doi.org/10.1111/rec.12011

Billé, R., J. P. Le Duc, and L. Mermet. 2010. Global biodiversity targets: vain wishes or significant opportunities for biodiversity governance? Pages 45-86 in R. Billé, L. Chabason, C. Chiarolla, M. Jardin, G. Kleitz, J. P. Le Duc, and L. Mermet, editors. Global governance of biodiversity: new perspectives on a shared challenge. Institute Français des Relations Internationales, Paris, France.

Bullock, J. M., J. Aronson, A. C. Newton, R. F. Pywell, and J. M. Rey-Benayas. 2011. Restoration of ecosystem services and biodiversity: conflicts and opportunities. Trends in Ecology and Evolution 26:541-549. http://dx.doi.org/10.1016/j.tree.2011.06.011

Castro, M. F. 2011. Defining and using performance indicators and target in government M\&E systems. PREM notes. Special Series on the Nuts and Bolts of M\&M Systems. Number 12. World Bank Poverty and Economic Management Network, Washington, D.C., USA. [online] URL: http://siteresources. worldbank.org/INTPOVERTY/Resources/335642-1276521901256/ ME12 v2.pdf

Convention for Biodiversity (CBD). 2010a. Decision X/2. Strategic plan for biodiversity 2011-2020 and the Aichi biodiversity targets, Nagoya, Japan, 18-29 October 2010. [online] URL: $\underline{\text { https://www.cbd.int/decision/cop/default.shtml?id=12268 }}$

Convention for Biodiversity(CBD). 2010b. Ecosystem services. Secretariat of the Convention on Biological Diversity, Montreal, Quebec, Canada. [online] URL: https://www.cbd.int/iyb/doc/ prints/factsheets/iyb-cbd-factsheet-ecoservices-en.pdf

Convention for Biodiversity (CBD). 2012. COP 11 Decision $\mathrm{XI} / 16$. Ecosystem restoration. Eleventh meeting of the Conference of the Parties to the Convention on Biological Diversity, 8-19 October 2012, Hyderabad, India [online] URL: https://www.cbd.int/decision/cop/?id=13177

Egoh, B. N., M. L. Parcchini, G. Zulian, J. P. Schägner, and G. Bidoglio. 2014. Exploring restoration options for habitats, species and ecosystem services in the European Union. Journal of Applied Ecology 51:899-908. http://dx.doi.org/10.1111/1365-2664.12251

European Commission. 2010. Options for an EU vision and target for biodiversity beyond 2010. Communication From the Commission to the European Parliament, the Council, the European Economic and Social Committee, and the Committee of the Regions. COM(2010) 4 final. [online] URL: http://eur-lex. europa.eu/legal-content/EN/TXT/PDF/?uri=CELEX:52010DC$\underline{0004 \& \text { rid }=1}$

European Commission. 2011a. Our life insurance, our natural capital: an EU biodiversity strategy to 2020. Communication From the Commission to the European Parliament, the Council, the Economic and Social Committee, and the Committee of the Regions. $\operatorname{COM}(2011) 244$ final. [online] URL: http://eur-lex. europa.eu/legal-content/EN/TXT/?uri=CELEX:52011DC0244

European Commission. 2011b. Impact assessment. Commission staff working paper. Communication From the Commission to the European Parliament, the Council, the European Economic and Social Committee and The Committee of the Regions. SEC
(2011) 540 final. [online] URL: http://ec.europa.eu/environment/ nature/biodiversity/comm2006/pdf/2020/1_EN_impact_assesment part1 v4.pdf

European Committee of the Regions. 2010. Opinion of the Committee of the Regions on EU and international biodiversity policy beyond 2010. ENVE-V-003. European Committee of the Regions, Brussels, Belgium. [online] URL: https://webapi.cor. europa.eu/documentsanonymous/CDR112-2010 FIN AC-EN.doc/ content

Hobbs, R. J., and J. A. Harris. 2001. Restoration ecology: repairing the Earth's ecosystems in the new millennium. Restoration Ecology 9:239-246. http://dx.doi.org/10.1046/ j.1526-100x.2001.009002239.x

Jänicke, M., and H. Jörgens. 2006. New approaches to environmental governance. Pages 167-209 in M. Jänicke and K. Jacob, editors. Environmental governance in global perspective: new approaches to ecological modernisation. Freie Universität, Berlin, Germany.

Jones, J. P. G., B. Collen, G. Akinson, P. W. J. Baxter, P. Bubb, J. B. Illian, T. E. Katzner, A. Keane, J. Loh, E. McDonald-Madden, E. Nicholson, H. M. Pereira, H. P. Possingham, A. S. Pullin A. S. L. Rodrigues, V. Ruiz-Gutierrez, M. Sommerville, and E. J. Milner-Gulland. 2011. The why, what, and how of global biodiversity indicators beyond the 2010 target. Conservation Biology 25:450-457. http://dx.doi.org/10.1111/j.1523-1739.2010.01605. $\underline{\mathrm{X}}$

Jørgensen, D. 2013. Ecological restoration in the Convention on Biological Diversity targets. Biodiversity and Conservation 22:2977-2982. http://dx.doi.org/10.1007/s10531-013-0550-0

Lammerant, J., R. Peters, M. Snethlage, B. Delbaere, I. Dickie, and G. Whiteley. 2013. Implementation of 2020 EU Biodiversity Strategy: priorities for the restoration of ecosystems and their services in the EU. Report to the European Commission. ARCADIS (in cooperation with ECNC and Eftec), Gent, Belgium. [online] URL: http://ec.europa.eu/environment/nature/ biodiversity/comm2006/pdf/2020/RPF.pdf

Mace, G. M., W. Cramer, S. Díaz, D. P. Faith, A. Larigauderie, P. Le Prestre, M. Palmer, C. Perrings, R. J. Scholes, M. Walpole, B. A. Walther, J. E. M. Watson, and H. A. Mooney. 2010. Biodiversity targets after 2010. Current Opinion in Environmental Sustainability 2:3-8. http://dx.doi.org/10.1016/j.cosust.2010.03.003

Mace, G. M., K. Norris, and A. H. Fitter. 2012. Biodiversity and ecosystem services: a multilayered relationship. Trends in Ecology \& Evolution 27:19-26. http://dx.doi.org/10.1016/j.tree.2011.08.006

Mace, G. M., C. Perrings, P. Le Prestre, W. Cramer, S. Díaz, A. Larigauderie, R. J. Scholes, and H. A. Mooney. 2013. Science to policy linkages for the post-2010 biodiversity targets. Pages 291-310 in B. Collen, N. Pettorelli, J. E. M. Baillie, and S. M. Durant, editors. Biodiversity monitoring and conservation: bridging the gap between global commitment and local action. Wiley-Blackwell, Chichester, UK. http://dx.doi.org/10.1002/978$\underline{1118490747 . \operatorname{ch} 13}$

Maes, J., J. Hauck, M. L. Paracchini, O. Ratamäki, M. Hutchins, M. Termansen, E. Furman, M. Pérez-Soba, L. Braat, and G. Bidoglio. 2013. Mainstreaming ecosystem services into EU policy. 
Current Opinion in Environmental Sustainability 5:128-134. http:// dx.doi.org/10.1016/j.cosust.2013.01.002

Matzdorf, B., and C. Meyer. 2014. The relevance of the ecosystem services framework for developed countries' environmental policies: a comparative case study of the US and EU. Land Use Policy 38:509-521. http://dx.doi.org/10.1016/j.landusepol.2013.12.011

National Audit Office. 2001. Measuring the performance of government departments. Stationary Office, London, UK.

Neßhöver C., J. Aronson, J. N. Blignaut, D. Lehr, A. Vakrou, and H. Wittmer. 2011. Investing in ecological infrastructure. Pages 401-448 in P. ten Brink, editor. The economics of ecosystems and biodiversity in national and international policymaking. Earthscan, London, UK.

Quental, N., J. M. Lourenço, and F. Nunes da Silva. 2011. Sustainable development policy: goals, targets and political cycles. Sustainable Development 19:15-29. http://dx.doi. org/10.1002/sd.416

Society for Ecological Restoration International Science \& Policy Working Group. 2004. SER international primer on ecological restoration. Version 2. Society for Ecological Restoration, Tucson, Arizona, USA.

Suding, K. N. 2011. Toward an era of restoration in ecology: successes, failures, and opportunities ahead. Annual Review of Ecology, Evolution, and Systematics 42:465-487. http://dx.doi. org/10.1146/annurev-ecolsys-102710-145115

Tuominen, A., and V. Himanen. 2007. Assessing the interaction between transport policy targets and policy implementation-a Finnish case study. Transport Policy 14:388-398. http://dx.doi. org/10.1016/j.tranpol.2007.04.002

Vandemoortele, J. 2009. The MDG conundrum: meeting the targets without missing the point. Development Policy Review 27:355-371. http://dx.doi.org/10.1111/j.1467-7679.2009.00451.x

Velázquez Gomar, J. O. 2014. International targets and environmental policy integration: the 2010 Biodiversity Target and its impact on international policy and national implementation in Latin America and the Caribbean. Global Environmental Change 29:202-212. http://dx.doi.org/10.1016/j. gloenvcha.2014.10.002

Young, T. P. 2000. Restoration ecology and conservation biology. Biological Conservation 92:73-83. http://dx.doi.org/10.1016/ S0006-3207(99)00057-9 